\title{
Editorial-In tribute to Geoff Burnstock
}

\section{Charles Kennedy ${ }^{1}$}

Published online: 4 February 2021

(C) The Author(s), under exclusive licence to Springer Nature B.V. part of Springer Nature 2021

With the death of Geoff Burnstock in June 2020, the scientific world lost a giant, and many of us lost a mentor and a friend. In this special issue of Purinergic Signalling, we pay tribute to Geoff and his achievements, with reviews from long-term associates who are senior workers in the field. We also highlight his contribution to and support of the numerous national Purine Clubs that he helped form.

Few people have single-handedly created a research field, but Geoff's energy and enthusiasm were an inspiration to so many people in the scientific community around the world. This is borne out by the number of contributors to the current issue or to the obituary published last year in issue 16(2), who explain that they didn't initially work on ATP or P2 receptors, but were inspired after hearing Geoff give one of his typically vibrant talks, to become "true believers" and move in that direction.
Geoff leaves behind a research field that is thriving and which will continue to grow and develop.

Dr. Charles Kennedy

Editor-in-Chief

Purinergic Signalling

\section{Declarations}

Conflict of interest Charles Kennedy declares that he has no conflict of interest.

Ethical approval This article does not contain any studies with human participants or animals performed by any of the authors.

Publisher's note Springer Nature remains neutral with regard to jurisdictional claims in published maps and institutional affiliations.
Charles Kennedy

c.kennedy@strath.ac.uk

1 Strathclyde Institute of Pharmacy \& Biomedical Sciences, University of Strathclyde, John Arbuthnott Building, 161 Cathedral St.,

Glasgow, Scotland G4 0RE, UK 